\title{
\#ISTS \\ Watershed Scale Response to Climate Change-South Fork Flathead River Basin, Montana
}

\section{Introduction}

General Circulation Model (GCM) simulations of future climate through 2099 project a wide range of possible scenarios (Intergovernmental Panel on Climate Change, 2007). To determine the sensitivity and potential effect of long-term climate change on the freshwater resources of the United States, the U.S. Geological Survey Global Change study, "An integrated watershed scale response to global change in selected basins across the United States" was started in 2008. The long-term goal of this national study is to provide the foundation for hydrologically based climate-change studies across the nation.

Fourteen basins for which the Precipitation Runoff Modeling System (PRMS) has been calibrated and evaluated were selected as study sites. PRMS is a deterministic, distributedparameter watershed model developed to evaluate the effects of various combinations of precipitation, temperature, and land use on streamflow and general basin hydrology. Output from five GCMs and four emission scenarios were used to develop an ensemble of climate-change scenarios for each basin. These ensembles were simulated with the corresponding PRMS model. This fact sheet summarizes the hydrologic effect and sensitivity of the PRMS simulations to climate change for South Fork Flathead River Basin in northwestern Montana (U.S. Geological Survey streamflow-gaging station 12362500; fig. 1) presented in the project summary report (Markstrom and others, 2012) and a journal article (Hay and others, 2011).

\section{Study Area}

The South Fork Flathead River Basin is located on the west side of the Continental Divide in northwestern Montana. It has a drainage area of 4,307 square kilometers $\left(\mathrm{km}^{2}\right)$ at South Fork Flathead River near Columbia Falls (streamflow-gaging station 12362500) downstream from Hungry Horse Reservoir (Berkas and others, 2004). This mountainous basin (elevation ranges from 1,045 to 2,078 meters) is undeveloped and covered mostly with forests that were affected by wildfires and mountain pine beetles during the 1998-2008 drought. The South Fork Flathead River flows into the Flathead River and ultimately into the Clark Fork of the Columbia River. Hungry Horse Reservoir, which was completed in 1952, on the South Fork Flathead River stores water that is used primarily for hydroelectric power generation, both onsite and at federal reservoirs downstream along the Columbia River system. Hungry Horse Reservoir also provides flood control as well as water for use in Montana and several downstream states for recreation, irrigation, fish protection, and fish migration.

The Bureau of Reclamation (BOR) maintains and operates the Hungry Horse Dam and Reservoir. Downstream requirements of stored water from the reservoir limit the use of this water in Montana. The U.S. Geological Survey, in cooperation with BOR, is using PRMS to simulate runoff in the South Fork Flathead Basin. The model will enable the BOR to forecast inflow to the reservoir and allow water-resource managers to optimize reservoir operations (Chase, 2011).

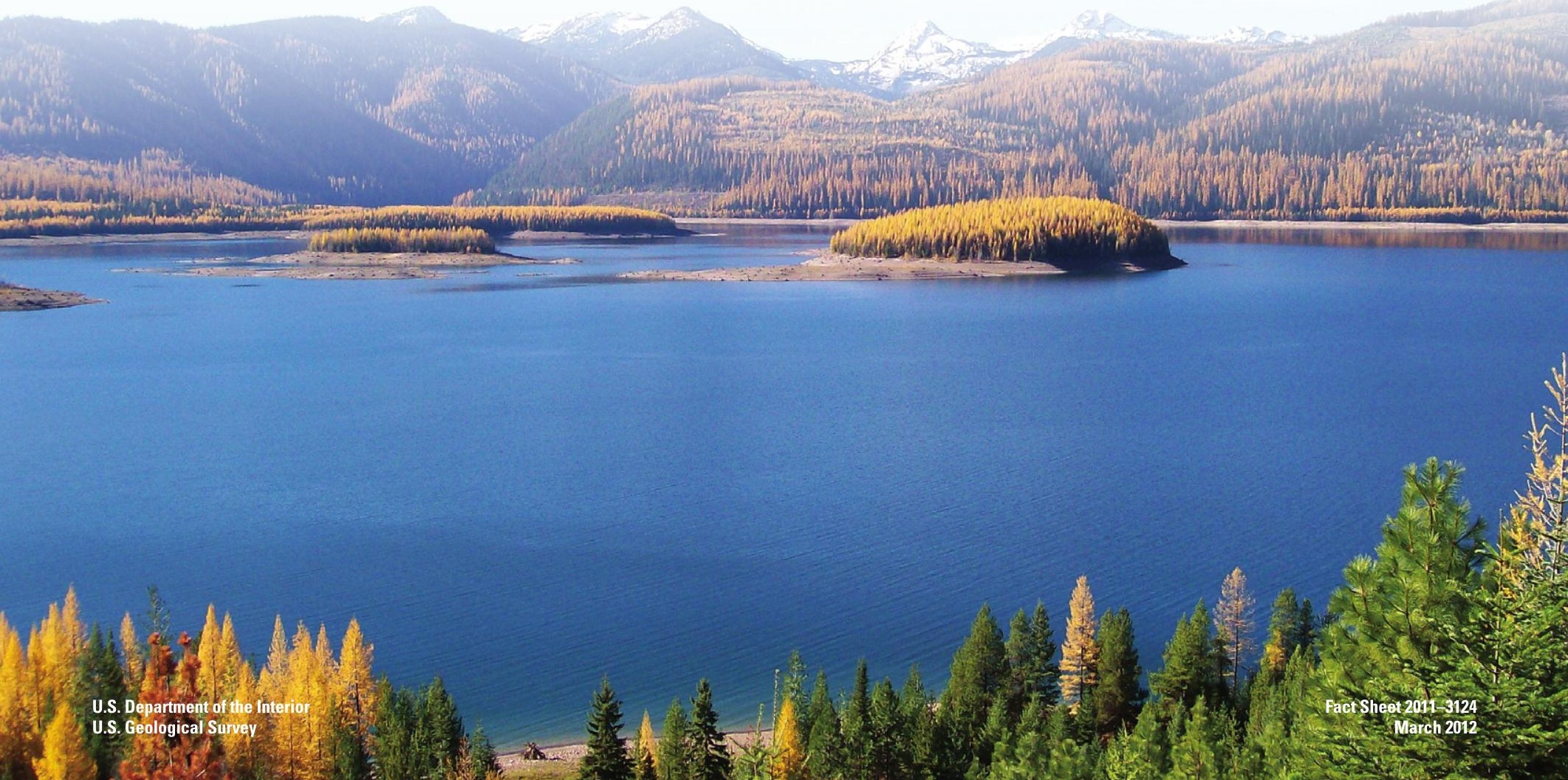



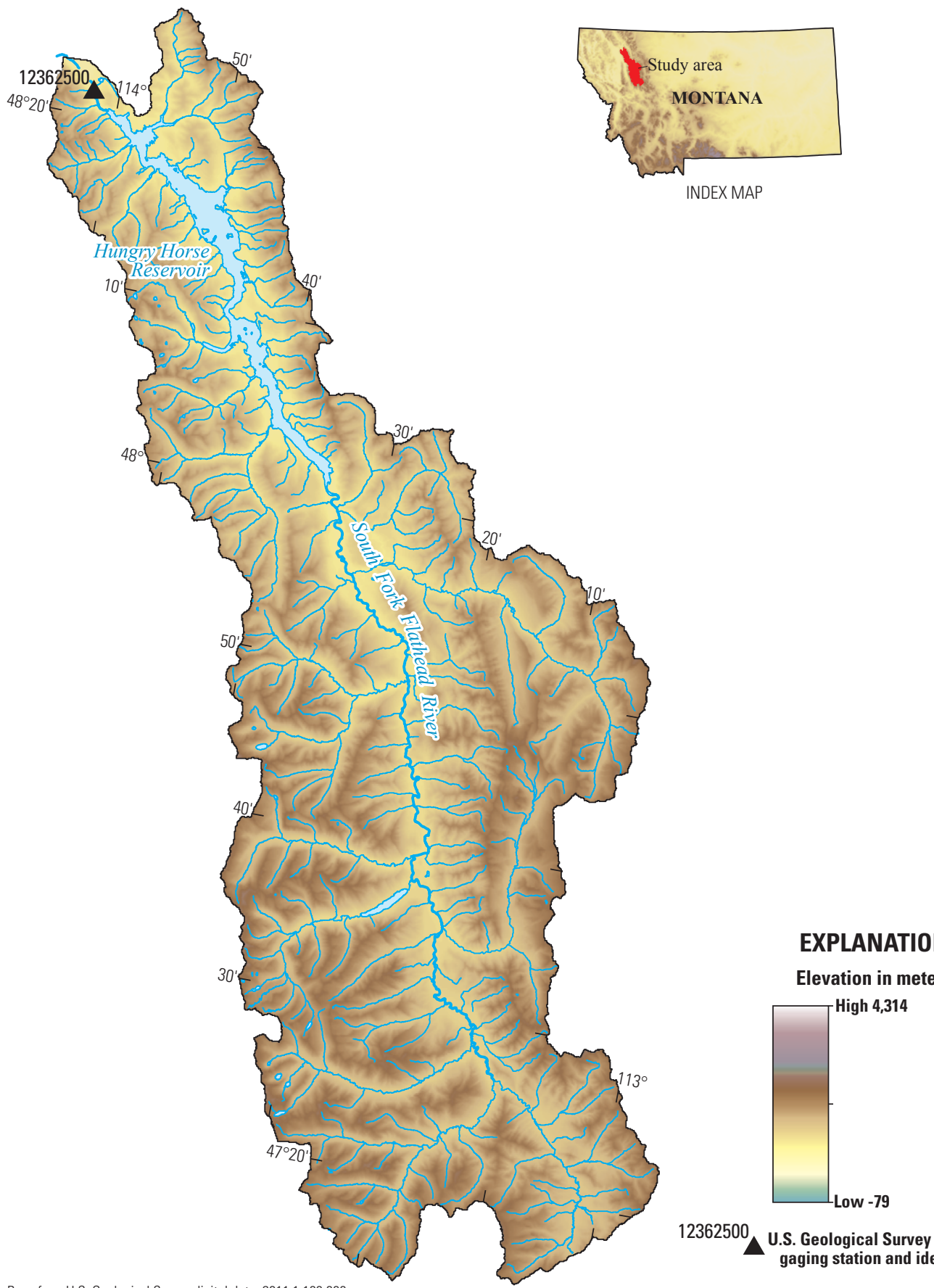

Base from U.S. Geological Survey digital data, 2011 1:100,000 Albers Equal-Area Conic projection

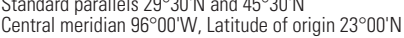

Horizontal coordinate information is referenced to the Horizontal coordinate information is referes
World Geodetic System of 1984 (WGS 84)

12362500 U.S. Geological Survey streamflowgaging station and identifier

Figure 1. Precipitation Runoff Modeling System study locations, South Fork of the Flathead River Basin, Montana, and location of U.S. Geological Survey streamflow-gaging station 12362500 with a drainage area of 4,307 square kilometers and elevation range from 1,045 to 2,078 meters. 


\section{General Circulation Models}

Given the uncertainty in climate modeling, it is desirable to use more than one GCM to obtain a range of potential future climatic conditions. Monthly precipitation and temperature output from five GCMs was processed (table 1).

Table 1. General Circulation Model (GCM) projections used in this study.

\begin{tabular}{ll}
\hline \multicolumn{1}{c}{ GCM } & \multicolumn{1}{c}{ Center and country of origin } \\
\hline BCC-BCM2.0 & Bjerknes Centre for Climate Research, Norway \\
CSIRO-Mk3.0 & Australia's Commonwealth Scientific and Industrial Research Organization, Australia \\
CSIRO-Mk3.5 & Australia's Commonwealth Scientific and Industrial Research Organization, Australia \\
INM-CM3.0 & Institute for Numerical Mathematics, Russia \\
MIROC3.2 & National Institute for Environmental Studies, Japan \\
\hline
\end{tabular}

The GCM outputs were obtained from the World Climate Research Programme's Coupled Model Intercomparison Project phase 3 multi-model dataset archive, which was referenced in the Intergovernmental Panel on Climate Change Fourth Assessment Special Report on Emission scenarios (Intergovernmental Panel on Climate Change, 2007). For each GCM, one current (water years 1988-1999) and three future emission scenarios were used and are described in table 2.

Table 2. Climate-change emission scenarios simulated by the General Circulation Models in this study.

\begin{tabular}{ll}
\hline \multicolumn{1}{c}{ Emission scenario } & Description/assumptions \\
\hline 20C3M & $\begin{array}{l}\text { 20th century climate used to determine baseline (1989-1999) conditions } \\
\text { Rapid economic growth, a global population that peaks in mid-21st century and rapid introduction of new and } \\
\text { more efficient technologies with a balanced emphasis on all energy sources } \\
\text { Convergent world, with the same global population as Emission scenario A1B, but with more rapid changes in } \\
\text { economic structures toward a service and information economy that is more ecologically friendly }\end{array}$ \\
A2 & Heterogeneous world with high population growth, slow economic development, and slow technological change \\
\hline
\end{tabular}

Climate-change fields were derived by calculating the change in climate from current (water years 1988-1999) to future conditions simulated by each GCM. The 20C3M simulation for water years 1988-1999 was used to represent current climatic conditions. This 12-year period of record was chosen based on the overlap of the available historical records from the 14 basins included in the national study. Climate change fields (percentage changes in precipitation and degree changes in temperature) were computed for 12-year moving window periods (from 2001-2099) using the 20C3M (1988-1999) and the A1B, B1, and A2 emission scenarios. A 12-year moving window, starting in 2001 and ending in 2099, results in 1,320 future scenarios $[(88,12$-year climatologies, 1 per year starting with 2001-2012 and ending with 2088-2099) x (3 emission scenarios) x (5 GCMs)].

Climate-change scenarios were generated for PRMS by modifying PRMS precipitation and temperature inputs with the mean monthly climate change fields derived from the GCMs, resulting in 1,320 PRMS-input files. Table 3 shows the change (slope) and adjusted $\mathrm{R}^{2}$ (adjR2) for the least squares fit to the trend line for selected output variables from the PRMS projections. The slope indicates the change in the selected variable by year. The adjusted $\mathrm{R}^{2}$ value gives an indication of the variability in the central tendency of the trend line.

Figure 2 shows a summary of the projected range in 11-year moving mean daily values of maximum temperature (fig. $2 A$ ), minimum temperature (fig. $2 B$ ), and precipitation (fig. $2 C$ ) by emission scenario. The first year of each 12-year simulation was used as PRMS initialization and is not included in the results. The three solid-colored lines indicate the 11-year moving mean values ( $\mathrm{x}$-axis indicates center of 11-year window) for the three future emission scenarios (central tendency of the five GCMs for each emission scenario). The projected range shown for each emission scenario indicates the range of potential future climatic conditions simulated by the five GCMs. All GCM simulations project steady increases in maximum and minimum temperature (table 3), with uncertainties associated with these GCM projections increasing with time. Both minimum and maximum temperatures show the smallest projected changes for the B1 emission scenario. Projected changes in mean annual precipitation for the South Fork Flathead River watershed are variable, with an overall positive trend in the central tendencies projected for the A1B emission scenario (table 3). The wide range in the precipitation projections indicates a large amount of uncertainty.

\section{Results}

PRMS simulates spatially distributed streamflow, components of flow (surface, subsurface, and groundwater), snowpack conditions, and many other hydrologic components of interest. Figure 3 shows the projected range in 11-year moving mean daily values of streamflow, precipitation that falls as snow, snowpack water equivalent, and soil moisture by emission scenario. The central tendency of the five GCMs for each of the three emission scenarios (indicated by the solid-colored lines) 

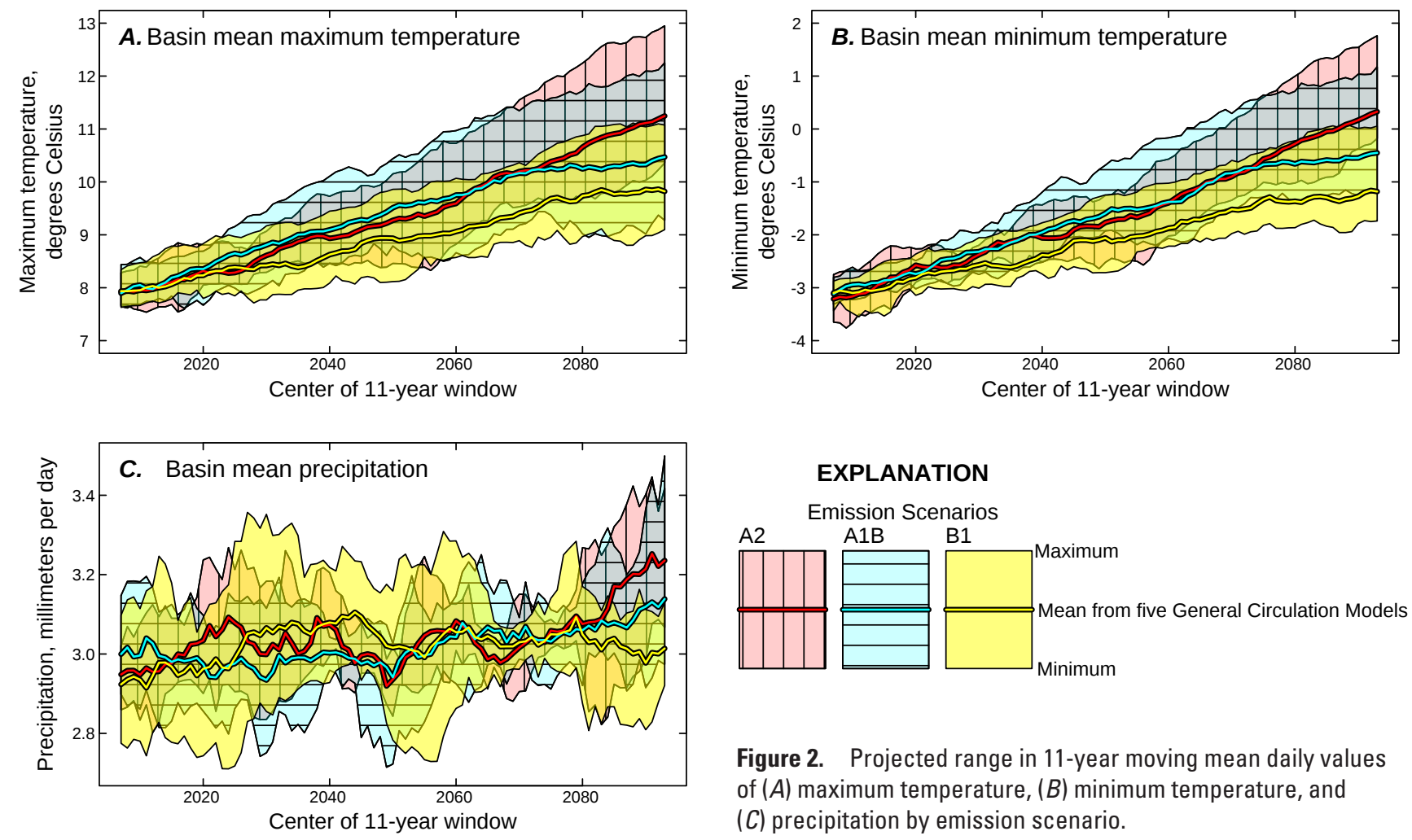

Figure 2. Projected range in 11-year moving mean daily values of $(A)$ maximum temperature, $(B)$ minimum temperature, and (C) precipitation by emission scenario.

Table 3. Projected change by year (slope) and adjusted $R^{2}$ (adjR2) based on the central tendencies of the five General Circulation Models for the three carbon emission scenarios for selected Precipitation Runoff Modeling System (PRMS)output variables.

[Blue indicates a significant negative trend and yellow indicates a significant positive trend $(\mathrm{p}<0.05)$ accounting for lag- 1 autocorrelation].

\begin{tabular}{|c|c|c|c|c|c|c|}
\hline \multirow{2}{*}{ PRMS output variable } & \multicolumn{2}{|c|}{$\begin{array}{c}\text { Emission scenario } \\
\text { A1B } \\
\end{array}$} & \multicolumn{2}{|c|}{$\begin{array}{c}\text { Emission scenario } \\
\text { A2 } \\
\end{array}$} & \multicolumn{2}{|c|}{$\begin{array}{c}\text { Emission scenario } \\
\text { B1 } \\
\end{array}$} \\
\hline & slope & $\operatorname{adjR2}$ & slope & $\operatorname{adjR2}$ & slope & $\operatorname{adj} R 2$ \\
\hline Maximum temperature in degrees Celsius & 0.031 & 0.98 & 0.040 & 0.99 & 0.024 & 0.98 \\
\hline Minimum temperature in degrees Celsius & 0.033 & 0.99 & 0.040 & 0.98 & 0.024 & 0.98 \\
\hline Precipitation in millimeters per day & 0.0040 & 0.87 & 0.0049 & 0.69 & 0.0022 & 0.51 \\
\hline Streamflow in cubic meters per second & 0.0547 & 0.41 & 0.0676 & 0.22 & -0.0010 & -0.01 \\
\hline Percent snow in percent per day & -0.18 & 0.97 & -0.21 & 0.95 & -0.13 & 0.94 \\
\hline Snowpack water equivalent in millimeters per day & -1.21 & 0.95 & -1.45 & 0.95 & -1.04 & 0.92 \\
\hline Snowmelt in millimeters per day & -0.0008 & 0.30 & -0.0010 & 0.17 & -0.0010 & 0.18 \\
\hline Soil moisture in millimeters per day & -0.0456 & 0.69 & -0.0760 & 0.86 & -0.0322 & 0.38 \\
\hline
\end{tabular}

projects an increase in mean annual streamflow for the A1B emission scenario only (table 3 ), though the uncertainties associated with each of the streamflow projections are large (fig. $3 \mathrm{~A}$ ). The streamflow projections follow the same oscillating trends as the precipitation projections shown in figure $2 C$. Because of the increase in minimum and maximum temperatures, the percentage of precipitation that falls as snow is projected to decrease in the basin (fig. 3B, table 3 ), with a corresponding decrease in snowpack water equivalent (fig. $3 C$, table 3 ). Figure $3 D$ shows decreasing soil moisture for the A1B and A2 emission scenarios (fig. $3 D$, table 3 ), indicating drier conditions in the basin by the end of the 21 st century.
Projected changes in streamflow are displayed on a monthly basis in figure 4 . The solid-red lines in figure 4 show PRMSsimulated mean monthly streamflow for current conditions (1989-1999). The boxplots represent the range in the projected mean monthly streamflow for the five GCMs and three scenarios for 2030 (green, 2025-2035), 2060 (tan, 2055-2065) and 2090 (blue, 2085-2095). The range of values indicated by the boxplots in figure 4 illustrate the high degree of uncertainty associated with the magnitude of these projected streamflow changes, especially during the months of April, May, and June. By the end of the 21st century, streamflow is projected to increase from November through April and decrease in May, 

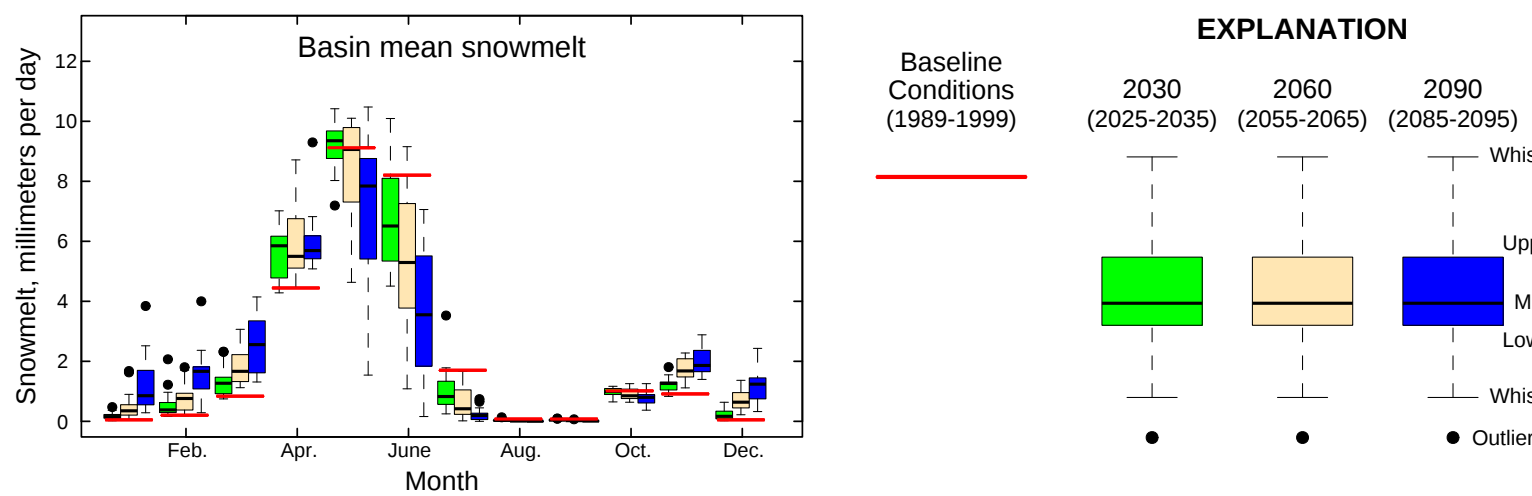

$\begin{array}{lccc}\text { Conditions } & 2030 & 2060 & 2090 \\ (1989-1999) & (2025-2035) & (2055-2065) & (2085-2095)\end{array}$

Figure 5. Mean daily snowmelt values by month for baseline conditions and projected range (2030, 2060, and 2090) using the five General Circulation Models and three emission scenarios.

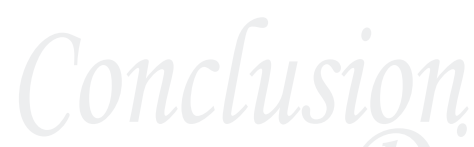

\section{Conclusion and Discussion}

Hungry Horse Reservoir, on the South Fork Flathead River, is an important component in the Columbia River system of reservoirs operated by the Bureau of Reclamation. A demand for the water stored in the reservoir is increasing and climate projections indicate that the quantity and timing of streamflow entering the reservoir could be changing. PRMS simulations using GCM scenarios indicate that flows could increase in the winter and early spring and decrease in late spring and through the summer. Uncertainty associated with the magnitude of these changes in streamflow is large. These results did not consider potential future land-cover dynamics; changes caused by forest fire or pine beetle damage could be important.

The combined effects of climate change and land-cover changes in the South Fork Flathead River Basin could affect water available for use in Montana and in downstream states. The scientific techniques described in the fact sheet can be augmented with other techniques in developing the science needed to address the combined effects of climate and land-cover dynamics on streamflow regimes.

\section{By Katherine J. Chase, Lauren E. Hay and Steven L. Markstrom}

For more information visit the following Web sites: http://wwwbrr.cr.usgs.gov/projects/SW_MoWS/

http://mt.water.usgs.gov/

http://www.usgs.gov/climate_landuse/

\section{Selected References}

Berkas, W.R., White, M.K., Ladd, P.B., Bailey, F.A., and Dodge, K.A., 2004, Water resources data, Montana, water year 2004, Volume 2, Yellowstone and Upper Columbia River Basins and ground water levels: U.S. Geological Survey Water-Data Report MT-04-02, 55 p.

Chase, K.J., 2011, Development of a precipitation-runoff model to simulate unregulated streamflow in the South Fork Flathead River Basin, Montana: U.S. Geological Survey Scientific Investigations Report 2011-5095, 39 p.

Hay, L. E., Markstrom, S.L., and Ward-Garrison, C.D., 2011, Watershed-scale response to climate change through the twenty-first century for selected basins across the United States, Earth Interactions, v. 15, 37 p.

Intergovernmental Panel on Climate Change, 2007, Summary for policymakers, in Climate change 2007-The physical science basis, Contributions of Working Group 1 to the Fourth Assessment Report of the Intergovernmental Panel on Climate Change: Cambridge and New York, Cambridge University Press, $18 \mathrm{p}$.

Markstrom, S.L., Hay, L.E., Ward-Garrison, C.D., Risley, J.C., Battaglin, W.A., Bjerklie, D.M., Chase, K.J., Christiansen, D.E., Dudley, R.W., Hunt, R.J., Koczot, K.M., Mastin, M.C., Regan, R.S., Viger, R.J., Vining, K.C., and Walker, J.F., 2012, An integrated watershed scale response to climate change for selected basins across the United States: U.S. Geological Survey Scientific Investigations Report 2011-5077, 142 p. 